\title{
Dimensions of Teachers' Expressed Capacity Building Needs on Climate Change Education Strategies
}

\author{
Emmanuel Eze ${ }^{1 *}$, Eric K.N. Nwagu ${ }^{1}$
}

\author{
${ }^{1}$ Faculty of Education, University of Nigeria Nsukka, NIGERIA \\ *Corresponding Author: eze.emma@unn.edu.ng
}

Citation: Eze, E., \& Nwagu, E. K. N. (2021). Dimensions of teachers' expressed capacity building needs on climate change education strategies. Interdisciplinary Journal of Environmental and Science Education, 17(4), e2251. https://doi.org/10.21601/ijese/10982

\begin{tabular}{|c|c|}
\hline ARTICLE INFO & ABSTRACT \\
\hline $\begin{array}{l}\text { Received: } \\
30 \text { December } 2020\end{array}$ & $\begin{array}{l}\text { Teaching is successful only when learning (a change in behaviour) is achieved. Diverse effective } \\
\text { strategies are employable by teachers to facilitate students' learning within the formal context of } \\
\text { climate change education (CCE), covering the cognitive, affective and psychomotor domains } \\
\text { corresponding to the head, heart and hands model. This quantitative study adopts a descriptive } \\
\text { survey research design to assess teachers' expressed capacity building needs in order to ascertain } \\
\text { gaps pertaining to effective teaching strategies related to the CCE-infused curriculum in Enugu } \\
\text { state. A total of } 410 \text { in-service public secondary school teachers serve as respondents in this study, } \\
\text { spread across four education zones within the study area. A self-developed questionnaire served as } \\
\text { the instrument for data collection in this study. This instrument passed face validity and reliability } \\
\text { tests (Alpha = .84). Descriptive statistics, mean, mean differences tests and exploratory } \\
\text { factor/dimension reduction analyses were applied to analyze data. Overall, teachers expressed high } \\
\text { capacity building need in most of the CCE strategies listed, irrespective of tested teacher variables. } \\
\text { Also, the results show two underlying factors/themes under which capacity building needs on the } \\
\text { listed CCE strategies are grouped - innovative, learner-centered/inclusive teaching strategies and } \\
\text { the use of instructional materials/media. Inference drawn from findings is that learner-centered } \\
\text { strategies/media are lacking in CCE, which would inhibit students' learning about climate change. } \\
\text { If the current trend is disregarded, achieving holistic CCE as captured by the head, heart and hands } \\
\text { model will be unattainable and with severe consequences on the future of the earth's environment. } \\
\text { Keywords: capacity building needs, climate change education, in-service teachers, teaching } \\
\text { strategies }\end{array}$ \\
\hline
\end{tabular}

\section{INTRODUCTION}

Teachers' frontline role within the formal education context, for steering learners towards a change of environmental behaviour, in the face of climate change is still sacrosanct (Herman et. al., 2017). The function of education as a response to the complexity of climate change, to promote willingness to take required actions for a better environment, has been reiterated by Mochizuki and Bryan (2015), who designate the aim of Climate Change Education (CCE) as the improvement of learners' understanding of climate change causes and consequences. Furthermore, CCE, as facilitated by teachers has been adjudged necessary for presenting useful information on climate change, while linking the climate change menace with daily human actions and choices (Eze, 2020). Specifically, previous studies have situated CCE (a component of Environmental Education) within school subjects such as Geography, Agricultural Science, Biology, Social studies and the Humanities (Eze, 2021; Hermans, 2016; Ho \& Seow, 2015; Karpudewan \& Khan, 2017; Ronald, Merab, \& Byalusaago, 2017; Siegner \& Stapert, 2019). Thus, the infusion of CCE in the curriculum of different school subjects, makes for expectations for increased climate change awareness among teachers who must facilitate the learning of the contents for students.

Copyright (C) 2021 by Author/s and Licensed by Veritas Publications Ltd., UK. This is an open access article distributed under the Creative Commons Attribution License which permit unrestricted use, distribution, and reproduction in any medium, provided the original work is properly cited. 
Such learning ought to prompt climate actions from learners. Climate action refers to activities aimed at climate change adaptation and mitigation to ensure a healthy and sustainable environment (Akrofi, et al. 2019).

The role of pedagogical strategies in effective CCE, which could ignite climate actions has been captured by Siegner (2018). Since the aim of CCE transcends information provision for learners to promoting a healthy environment, the best strategies ought to be employed by teachers in delivering CCE contents. Such effective CCE strategies have been identified from an encompassing systematic review of the literature by Monroe, Plate, Oxarart, Bowers and Willandia (2017) and themed broadly under two namely: relevant and meaningful information; and activity-based/engaging teaching strategies. Earlier studies, such as Doyle (2011), Davis and Arend (2013), have described successful teaching as such which facilitates learning and actively involves the learner in the process. Thus, a learner-centered approach for CCE becomes the ideal expectation for equipping people, especially the younger generation, to deal with future socio-environmental, economic and political uncertainties due to the changing climate (Bangay \& Blum, 2010).

However, CCE seem to be facing challenges. Oversby (2015) confirms that climate change contents are missing in teacher preparation contents, which imply that in-service teachers may be untrained in the contents and pedagogies of CCE. Also, the breadth and transdisciplinary nature of CCE, with the distantness of climate change impacts are other challenges facing the achievement of the goals of CCE (Moser, 2010; Oversby, 2015; UNFCCC, 2001). Furthermore, there appears to be a lack of consensus on the state of teachers' capacity on effective CCE strategies. While Monroe, Oxarart and Plate (2013) opine that environmental educators possess adequate conceptual background, and are fixed to facilitate learners' understanding of environmental issues for needed actions; conceptual, pedagogical and resource gaps have been reported among environmental educators (Cheng \& So, 2015).

In establishing climate confusion among science teachers in the United States of America, Plutzer et al. (2016) found the advancement of climate science outpacing teachers' training and available learning materials. Similarly, in addressing identified capacity gaps, Herman et al (2017) recommend training for improvement of Florida and Puerto Rico secondary science teachers' understanding of the nature and teaching techniques on climate change science to improve their naïve views on the subject. Some earlier studies have presented pedagogical gaps of CCE in Africa. For example, Ronald et al. (2017) report teaching without connections to real life climate change impacts in Uganda; Loubser and Simalumba (2016) indicate that aside content deficiencies, Namibian teachers did not apply varieties of teaching approaches; Duval and Kanene (2016) allude to 'examination-oriented teaching' of environmental education (EE) in Seychelles, which limits the attainment of the EE goals. Several studies conducted in different zones of Nigeria are limited to the assessment of teachers' climate change awareness with inconclusive outcomes. For example, low level of climate change awareness among teachers in the south-south; high level awareness and knowledge of topics on climate change in the southeast; very low awareness and perception of climate change as very low in the south-west (Ekpoh \& Ekpoh, 2011; Ikoro \& Ezeanyim, 2016; Dike \& Amadi, 2016; Ogunseemi \& Ibimilua, 2016). In addition, the study of Ozioko, Dimelu and Madukwe (2013) include poor understanding of climate change as part of the constraints to teaching capacity for adaptation to climate change in the University faculties of agriculture in south east, Nigeria.

In addressing these capacity gaps for effective implementation of CCE, in-service teacher professional trainings and programmes have been advocated by Dube (2014); and Cebesoy (2019). However, needs assessment must be conducted to identify specific competency gaps to be filled with capacity building programmes. Whereas Watkins, Meiers and Visser (2012) describe needs assessment as an information-gathering process, suitable for the development of effective programmes to address a groups' peculiar needs (gap); capacity building is the development of the knowledge, attitude and skills of individuals/workforce in an organization to their full capacity by the identification of areas requiring improvement (gaps) and filling up such gaps for performance-boosting (Awefeso, 2012; Castle, Tan, \& LaGro, 2015; Osinem \& Nwoji, 2010). Thus, needs assessment gives rise to the discovery of capacity building needs, which could be met using different means. For example, Nakpodia (2008) posit that inservice training programmes are necessary for uninterrupted update of teachers' skills and knowledge in specific issues. Hence, such programmes will present opportunities for continuous professional growth and up-to-date knowledge and skills for facilitation of contents for their learners.

This study, a needs assessment, aims at the identification of teachers' capacity building needs in effective strategies for CCE instruction in a bid to unveiling the pedagogical gaps of teachers for CCE. Since most of the studies currently available, some of which are captured in earlier sections of this work, 
address teachers' conceptual gaps in CCE, we focus on providing specific information on the nature of pedagogical gaps of teachers, which are likely to inhibit effective CCE contents' delivery. Findings of this study are expected to improve chances of achieving the goals of CCE within the classroom setting. The central, previously unanswered questions motivating this study are, 'what are teachers' expressed capacity building needs on effective CCE strategies?' Also, 'are there variables influencing teachers' capacity building needs on effective CCE strategies?'

\section{THEORETICAL FRAMEWORK}

This study follows the head, heart and hands (HHH) model. The head, heart and hands model introduced by Orr (1992) is chosen to provide theoretical foundation for this study because the model adopts a holistic approach to developing ecoliteracy and education for sustainability. The model will aid the description of missing domains of CCE based on teachers' expression of capacity building needs in corresponding strategies to the domains of the model. The aforementioned author asserts that "education should exceed contents or formal knowledge to capture value and meaning-creation". Such an approach to education considers the engagement of the intellect, emotion and body, as vital components of a transformative learning experience, where the cognitive domain (represented by 'head') relates to critical reflection; the affective domain (represented by 'heart') handles relational knowing, and the psychomotor domain (represented by 'hands') is reflected in engagement. Therefore, the head, heart and hands framework illustrates learners' advancing from knowing to caring, to loving to doing for the environment in the face of climate change. Effective CCE ought not to be limited to a singular domain of education (say, head cognitive). The affective (heart) and psychomotor (hands) domains must be included in facilitating CCE for learners.

Consequently, this capacity building needs assessment study lists 11 CCE strategies drawn from the literature and correspond to the three domains of learning (Table 1). Green (2012) mentions most of these strategies and more, as effective in promoting sustainability thinking among learners. Thus, these strategies are pivotal for meaningful learning. Ausubel (2000) describes meaningful learning as such that occurs when a learner successfully links up old knowledge with a new information. Authors such as Hill (2013); Casinader and Kidman (2017) has clarified the promise of fieldwork for education targeting sustainability. The gains of value education, role playing, peer teaching among others as problem- solving strategies for environmental education is contained in Ogunbiyi and Ajiboye (2009) while McPartland (2001) has called for the application of moral dilemmas in teaching (geography), to improve learners' ability to create reasoned arguments and concerns. The contribution of concept maps to transformative learning of $\mathrm{K}-12$ students is clarified by Campelo and Piconez (2016), whereas Osa and Musser (2004), have described posters as "an often neglected type of instructional material" yet inexpensive and useful, deserving a place in the collections and on the wall. In addition to cartoonbased strategies explored, Kleeman (2006) describes the possibilities of the simplification of complex issues and the development of learners' critical thinking ability with cartoons.

The positions of these studies recommending specific techniques as effective for CCE necessitate the selection of the CCE strategies used in this study. Thus, these strategies (Table 1) are presented in a questionnaire (Appendix 1), to elicit teachers' responses on which of them they (teachers) would require capacity building or training before application in the delivery of CCE contents.

\section{METHODS}

Design, Study Area, Population, Sampling Techniques and Data-Collection Instrument

Descriptive survey research design is followed by this study. The design is considered suitable for this study, as it entails the assembling of descriptions of expressed capacity building needs of teachers on environmental/climate change education. The study area covered by this research is Enugu state, Nigeria. Awgu, Enugu, Nsukka, and Obollo-Afor education zones were purposively used for this study out of a total of six zones within the state. Accessibility by public transportation and a considerable mix of teachers based on gender, location, academic qualifications and years of teaching experience are expected in these zones, influenced their choice for this study. All the 10,112 secondary school teachers in the 291 Enugu state public schools make up the population of this study (Federal Ministry of Education, 2017).

Since the population was unmanageable, sample determination was adopted from Yamane (1967) formula to obtain an ideal size of 385. A total of 500 copies of questionnaires was distributed to prevent shortfalls in the sample size, which may arise from low return-rate. The number of properly filled questionnaires returned was 410 . Hence, the sample size for this study is 410 secondary school teachers. To represent the earlier-chosen education zones, 
Table 1. Selected climate change education strategies and their respective domains

\begin{tabular}{cll}
\hline S/N & CCE strategy & Learning domain(s) covered \\
\hline 1 & Fieldwork & Head, heart and hands \\
2 & Projects & Head, heart and hands \\
3 & Value clarification & Head and heart \\
4 & Moral dilemma & Head and heart \\
5 & Role playing & Head, heart and hands \\
6 & Community based resources & Head, heart and hands \\
7 & Resource persons & Head, heart and hands \\
8 & Concept mapping & Head and hands \\
9 & Posters & Head, heart and hands \\
10 & Cartoons & Head, heart and hands \\
11 & Newspaper cuttings & Head, heart and hands \\
\hline
\end{tabular}

Awgu, Enugu East, Enugu North, Nsukka, Uzo-uwani and Udenu Local Government Areas (LGAs) were again purposively selected, based on the same earlier-mentioned reasons. To achieve randomization, every other teacher was chosen to complete the questionnaire. However, because some teachers declined, randomization was not fully achieved.

The self-developed instrument used for this study was captioned "Teachers' capacity building needs on climate change education strategies (TCBNCCES)" and split in two parts for pertinent data collection. The first part requested teacher-related information, while the second part listed 11 teaching strategies related to environmental/climate change education, in which teachers were to provide their level of capacity building needs. Items listed as teaching strategies are drawn largely from Ezeudu (2003); Makrakis, Larios and Kaliantzi (2012); and Oversby (2015). Three experts from environmental education, measurement and evaluation fields facevalidated the instrument to ascertain relevance and clearness of items. The reliability of the instrument was determined using Cronbach's alpha. The reliability coefficient obtained was 0.84 , which is designated 'good'. Thus, the instrument satisfies the validity and reliability criteria for use in this study and considered suitable.

\section{Data Collection, Analyses and Interpretation} Procedure Adopted

Standard ethical procedures were adopted in the data collection for this study. Approvals from school heads/administrators were obtained to access their teachers. Teachers were assured of the confidentiality of their responses, to increase the accuracy of their responses. Data was analysed using SPSS. Descriptive statistics, mean, $t$ test, ANOVA and exploratory factor analyses were adopted in answering the research questions guiding the study, with $\mathrm{p}<.05$ used as the level of significance. In describing the results related to teachers' expressed training needs in the listed teaching strategies, the following ranges are fixed: Not needed $(\bar{X}=1.0-1.49)$, Less needed ( $\bar{X}=1.5-2.49$ ), Moderately needed $(\bar{X}=2.5-3.49)$, Highly needed $(\bar{X}=3.5-4.49)$, and Very highly needed $(\bar{X}=4.5-5.0)$.

Exploratory factor analysis - principal component analyses (PCA), a data reduction technique was implemented to regroup the listed teaching strategies into a fewer number, to provide a clearer information based on related responses of teachers. Basically, PCA has been described as a useful analytical technique suitable for extraction of the most significant variables from a list of interrelated variables into a new set of uncorrelated variables called principal components. Thus, a large number of variables are aggregated into groups, which define a common underlying dimension (Anyadike, 2009). The Eigen values are the measure of covariance for the data, which are utilized in ranking the principal components in the order of significance (Otitoju \& Enete, 2016). Generally, the principal components of significance possess an Eigen value of 1.00 and above. Hence, PCA was carried out using SPSS and a varimax rotation with Kaiser normalization followed, with items loadings below 6 removed.

\section{RESULTS and DISCUSSION \\ Characteristics of Respondents}

Respondents' characteristics are presented in Table 2. Most respondents are females (65.1\%). In terms of location of service, urban teachers are more (67.3\%). The sampled population are nearly evenly distributed across academic disciplines of sciences (34.2\%), social sciences (32.2\%) and arts (32.9). Most respondents (68\%) possess a bachelor's degree, which is the basic requirement for secondary school teachers in public schools. Over 69\% of respondents have years of teaching experience, ranging from 0 to 10 years. Thus, responding teachers vary by gender and location, are spread 
Table 2. Frequency distribution of respondents by variables

\begin{tabular}{llllll}
\hline Variable & & $\mathrm{N}$ & $\%$ & Mean & $p$ \\
\hline \multirow{2}{*}{ Gender } & Male & 143 & 34.9 & 3.56 & .140 \\
& Female & 247 & 65.1 & 3.69 & .892 \\
Location & Rural & 134 & 32.7 & 3.65 & \\
& Urban & 276 & 67.3 & 3.64 & .759 \\
& Science & 143 & 34.9 & 3.63 & \\
Higciphestine & Social Sciences & 132 & 32.2 & 3.69 & .383 \\
& Arts & 135 & 32.9 & 3.61 & \\
qualification & NCE & 87 & 21.2 & 3.58 & \\
& B.Sc. and equivalent & 279 & 68.0 & 3.65 & .223 \\
Years of & PhD. and equivalent & 41 & 10.0 & 3.68 & \\
teaching & 1 - 5 years & 3 & 0.7 & 4.45 & \\
experience & 6 10 years & 130 & 31.7 & 3.57 & \\
& 16 - 15 years & 154 & 37.6 & 3.60 & \\
& $>$ 20 years & 51 & 12.4 & 3.68 & \\
\end{tabular}

through the major disciplines, and with different ranges of years of teaching experiences. Robust responses and results were expected.

Teachers' Expressed Capacity Building Needs on Teaching Strategies for Effective Environmental and Climate Change Education

Teachers indicated their capacity building need from the listed teaching strategies (Table 3). Their responses range from moderately needed to highly needed. Based on the mean score of each respondent, teachers' variables tested had no significant influence on their capacity building needs (Table 2 ).
Principal Component Analyses (PCA) of Teachers' Capacity Building Needs on Teaching Strategies for Effective Environmental and Climate Change Education

Firstly, collated data was assessed to determine suitability for factor analysis before conducting PCA. The Kaiser-Meyer-Orkin value (.920) exceeded the recommendation of '.6' (Kaiser, 1974). Bartlett's test of sphericity significant value (.000) indicates the factorability of the data. Principal component analysis results indicated that there were two components with eigenvalues above 1 , explaining $61.91 \%$ of the total variance in the data set. These

Table 3. Capacity building need of teachers on teaching strategies

\begin{tabular}{|c|c|c|c|c|c|c|c|c|}
\hline & \multirow{2}{*}{ Teaching strategies } & \multicolumn{5}{|c|}{ Extent of capacity building need (\%) } & \multirow{2}{*}{ Mean } & \multirow{2}{*}{ Remarks } \\
\hline & & 1 & 2 & 3 & 4 & 5 & & \\
\hline 1 & Field work & 7.1 & 9.0 & 19.5 & 29.5 & 34.9 & 3.76 & Highly needed \\
\hline 2 & Projects & 3.9 & 13.9 & 18.0 & 33.7 & 30.5 & 3.73 & Highly needed \\
\hline 3 & Value clarification & 5.9 & 13.2 & 20.2 & 32.0 & 28.8 & 3.65 & Highly needed \\
\hline 4 & Moral dilemma & 8.0 & 14.4 & 24.1 & 30.0 & 23.4 & 3.46 & Moderately needed \\
\hline 5 & Role playing & 5.9 & 12.2 & 22.2 & 32.4 & 27.3 & 3.63 & Highly needed \\
\hline 6 & $\begin{array}{l}\text { Community-based } \\
\text { resources }\end{array}$ & 3.7 & 10.7 & 15.1 & 34.1 & 36.3 & 3.89 & Highly needed \\
\hline 7 & Resource persons & 4.6 & 11.5 & 16.6 & 29.3 & 38.0 & 3.85 & Highly needed \\
\hline 8 & Concept mapping & 6.6 & 10.2 & 21.5 & 32.4 & 29.3 & 3.68 & Highly needed \\
\hline 9 & Posters & 7.6 & 13.9 & 20.0 & 31.5 & 27.1 & 3.57 & Highly needed \\
\hline $\begin{array}{l}1 \\
0\end{array}$ & Cartoons & 11.7 & 14.9 & 25.1 & 22.9 & 25.4 & 3.35 & Moderately needed \\
\hline $\begin{array}{l}1 \\
1\end{array}$ & Newspaper cuttings & 9.5 & 10.7 & 22.4 & 28.8 & 28.5 & 3.56 & Highly needed \\
\hline & & & & & $\mathrm{Clu}$ & mean & 3.64 & Highly needed \\
\hline
\end{tabular}

Note: 1 =Not needed; $2=$ Less needed; 3=Moderately needed' $4=$ Highly needed; 5=Very highly needed 
first and second components respectively explained $36.46 \%$ and $25.44 \%$ of all variations (Table 4 ). Therefore, PCA shows that teachers' capacity building need are summarized under two underlying dimensions, as deduced from the variances of the two extracted components (Table 5).

\section{Interpretation of The Components \\ Component One}

The Eigen value of 4.011 loaded positively on seven items (Table 4,5). These positive and significant items on this component include fieldwork, projects, value clarification, role playing, community based resources, resource persons, and concept mapping. Thus, teachers require high capacity building in the listed techniques (Table 3) and thus do not apply them in the delivery of CCE in the classroom. Since teachers' express high capacity building need on these CCE strategies, we infer that these vital strategies are lacking in the classroom, and is inimical to the achievement of CCE goals. These findings agree with Loubser and Simalumba (2016), who indicate that Namibian teachers did not apply variety of teaching strategies in EE classes. Similarly, Değirmenci and Ilter (2017) show that teachers in a part of Turkey were limited to the use of teachercentered strategies and did not adopt studentcentered activities in their teaching. The possibility of disjointed and examination-oriented CCE contents' delivery as reported elsewhere may be the result of these pedagogical gaps identified (Duval, 2016; Ronald et al., 2017).

From the derived grouping of the seven techniques within this component, the underlying dimension of teacher capacity building need for CCE contents delivery has been themed 'innovative and learner-centered teaching strategies'. Whereas fieldwork, projects, value clarification, role playing

Table 4. Total variance explained by PCA

\begin{tabular}{|c|c|c|c|c|c|c|c|c|c|}
\hline \multirow[t]{2}{*}{ Component } & \multicolumn{3}{|c|}{ Initial Eigenvalues } & \multicolumn{3}{|c|}{$\begin{array}{c}\text { Extraction Sums of Squared } \\
\text { Loadings }\end{array}$} & \multicolumn{3}{|c|}{$\begin{array}{c}\text { Rotation Sums of Squared } \\
\text { Loadings }\end{array}$} \\
\hline & Total & $\begin{array}{c}\% \text { of } \\
\text { Variance }\end{array}$ & Cumulative \% & Total & $\begin{array}{c}\% \text { of } \\
\text { Variance }\end{array}$ & Cumulative \% & Total & $\begin{array}{c}\% \text { of } \\
\text { Variance }\end{array}$ & Cumulative $\%$ \\
\hline 1 & 5.742 & 52.200 & 52.200 & 5.742 & 52.200 & 52.200 & 4.011 & 36.467 & 36.467 \\
\hline 2 & 1.068 & 9.707 & 61.907 & 1.068 & 9.707 & 61.907 & 2.798 & 25.440 & 61.907 \\
\hline 3 & .775 & 7.047 & 68.954 & & & & & & \\
\hline 4 & .647 & 5.879 & 74.834 & & & & & & \\
\hline 5 & .513 & 4.667 & 79.501 & & & & & & \\
\hline 6 & .450 & 4.090 & 83.591 & & & & & & \\
\hline 7 & .427 & 3.882 & 87.473 & & & & & & \\
\hline 8 & .400 & 3.640 & 91.113 & & & & & & \\
\hline 9 & .382 & 3.468 & 94.582 & & & & & & \\
\hline 10 & .318 & 2.888 & 97.470 & & & & & & \\
\hline 11 & .278 & 2.530 & 100.000 & & & & & & \\
\hline
\end{tabular}

Extraction Method: Principal Component Analysis.

Table 5. Rotated component matrix of the PCA

1 2

\begin{tabular}{|c|c|c|}
\hline Fieldwork & $.781^{*}$ & \\
\hline Projects & $.823^{*}$ & \\
\hline Value clarification & $.686^{*}$ & \\
\hline Moral dilemma & excluded & \\
\hline Role playing & $.632^{*}$ & \\
\hline Community based resources & $.724^{*}$ & \\
\hline Resource persons & $.720 *$ & \\
\hline Concept mapping & $.629 *$ & \\
\hline Posters & & $.719^{*}$ \\
\hline Cartoons & & $.812^{*}$ \\
\hline Newspaper cuttings & & $.844^{*}$ \\
\hline
\end{tabular}

Extraction Method: Principal Component Analysis.

Rotation Method: Varimax with Kaiser Normalization.

*Significant loadings exceeding +/-0.60 
and concept mapping will involve the students in the learning experiences within the CCE classroom and regarded as learner-centered teaching strategies, the use of community-based resources and invitation of resource persons to the CCE classroom are innovative strategies, which are distinct from the conventional lecture strategies adopted by majority of teachers. Teachers ought to be versed in these strategies, which are effective in CCE contents (Amahmid et al., 2019; Eze, 2020; UNESCO, 2017).

Useful insights from previous studies indicate that environmental and sustainability educational experiences should minimize lecturing to embrace 'more engaging, hands-on and learner-centered pedagogies' for better learning. Such pedagogies aid students process and synthesize complex multidisciplinary environmental information to arrive at desired human-environmental actions. Aside the learning outcomes in the use of these strategies, their application by teachers boost students' engagement, and makes learning more fun for both the teacher and learners (Byrne, 2016; Kober, 2015). Considering the listed CCE strategies as touching all the three learning domains (cognitive, affective and psychomotor), which corresponds to the head, heart and hands model, it behooves teachers to seek (re)training on the listed strategies and more, for effective implementation and achievement of CCE goals. Notably, essential elements of the respective strategies must be captured in future professional development of teachers to ensure the benefits of adopting these strategies are maximally obtained.

\section{Component Two}

The Eigen value of 2.798 defines this component (Table 4). The three items captured within component two include posters, cartoons and newspaper cuttings. Posters and newspaper cuttings are printed teaching materials, while cartoons could take printed or media forms. These three items as distinctly placed under component two are named 'instructional materials/media'. Whereas teachers require high capacity building in the use of posters and newspaper cuttings for CCE, they express moderate capacity building need on the use of cartoons. This result denotes teacher-dominated instructions and the absence of these important elements of effective teaching (using materials and media) in CCE classrooms.

Effective CCE delivery cannot be achieved without relevant instructional materials and media. Dlamini (2016) suggests that audio-visual resources such as posters should be sufficiently available for CCE. Similarly, Kutze et al (2015) posit that posters are useful for increasing awareness in environmental issues. Other studies have found the relevance of newspapers and cartoons in actively engaging learners; simplifying complex issues into simpler forms; strengthening learners' grasp of concepts; improved analysis of environmental issues and making learning fun (Değirmenci \& Ilter, 2017; Jenkins \& Keene, 1979; Kleeman, 2006; Oluk \& Ozalp, 2007; Toledo, et al., 2014).

The seldom attention in the literature may be a core reason for the neglect of posters. This earlier position by Osa and Musser (2004) is still valid. Also, we opine that the use of cartoons and newspapers are rare in CCE classrooms because teachers are not exposed to these beneficial strategies cum instructional media for effective and engaging CCE. These instructional media place students in-charge of their learning, and improves the likelihood of learners' positive disposition towards the environment in the face of climate change. Onuoha and Eze (2013) had recommended the equipment of learning environments with electronic and nonelectronic teaching/learning materials sourced either locally or abroad to improve positive attitudes towards learning.

\section{CONCLUSION}

This study ascertained gaps pertaining to CCE strategies assessed by collating teachers' expressed capacity building needs on these strategies. From the findings of the study, teachers express high capacity building need on two central themes of the listed strategies (i.e. innovative, learner-centered/inclusive teaching strategies and the use of instructional materials/media). Also, the teacher variables tested had no statistical significance on teachers' expressed capacity building needs. Teachers' high capacity building needs on learner-centered strategies and instructional materials/media are across all gender, location, discipline, educational qualification and irrespective of years of teaching experience. If the current trend is disregarded, the opportunity for engaging students in holistic CCE as captured by the head, heart and hands model, which includes all the domains of learning (cognitive, affective and psychomotor) will be missed. This has severe consequences for present actions, with a greater burden on the future of the earth's environment. Questions on the quality of preservice teacher trainings and the scope of professional development programmes arise from this study and may require future investigation to ascertain whether explicit efforts are made to train teachers on effective strategies for CCE.

\section{ACKNOWLEDGMENTS}

This work is drawn from a portion of the lead author's master degree research, supervised by the 
co-author. Professor S. A. Ezeudu, Dr. J.C. Onuoha Dr F. Ikeh, Dr S. O. Ugwuda and Dr S. N. Ogbueghu provided invaluable assistance and critical suggestions during the formative stage of this study. The contribution of the seven trained research assistants aided the data collection for this study. We thank the school principals for the approvals granted, and the teachers who accepted to participate in this study. The University of Nigeria, Nsukka, granted a fee rebate to the lead author during the programme. The contributions of anonymous reviewers and coordinating editor improved the published manuscript.

\section{Funding}

This research did not receive any grant from funding agencies in the public, commercial, or notfor-profit sectors.

\section{Declaration of competing interests}

The authors declare no competing interests.

\section{Orcid}

Emmanuel Eze - https://orcid.org/0000-00032007-2696

\section{REFERENCES}

Akrofi, M. M., Antwi, S. H., \& Jabulani, R. G. (2019). Students in climate action: A study of some influential factors and implications of knowledge gaps in Africa. Environments, 6(12), 1-15. https://doi.org/10.3390/environments6020012

Amahmid, O., El Guamri, Y., Yazidi, M., Razoki, B., Rassou, K.K., Rakibi, Y., Knini, G., \& El Ouardi, T. (2019). Water education in school curricula: Impact on children knowledge, attitudes and behaviours towards water use. International Research in Geographical and Environmental Education, 28(3), 178-193. https://doi.org/10.1080/10382046.2018.1513446

Anyadike RNC (2009). Statistical Methods for the Social Sciences. Ibadan: Spectrum Books Limited; 2009.

Ausubel, D. P. (2000). The acquisition and retention of knowledge: A cognitive view. Boston, MA. Kluwer.

Awefeso, N. (2012). Organisational capacity building in health systems. Canada: Routledge Publishers

Bangay, C., \& Blum, N. (2010). Education responses to climate change and quality: Two parts of the same agenda? International Journal of Educational Development, 30(4), 335-450.

Byrne, L. B. (2016). Learner-centered teaching activities for environmental and sustainability studies. Springer: International Publishing Switzerland. https://doi.org/10.1007/978-3-319-28543-6

Campelo, L. F., \& Piconez, S. C. B. (2016). Concept mapping in high school: An experience on teaching geography to measure deep, surface and non-learning outcomes. In: Cañas, A.; Reiska, P.; Novak, J. (Eds.)
Innovating with Concept Mapping. Springer Communications in Computer and Information Science (CCIS), 635, 29-39.

Casinader, N., \& Kidman, G. (2017). Fieldwork, sustainability, and environmental education: The centrality of geographical inquiry. Australian Journal of Environmental Education, 34(1), 1-17.

Castle, M. A., Tan, N., \& LaGro, J. A. (2015). Evaluating capacity building to foster climate change adaptation. Open Journal of Social Sciences, 3, 81-90. http://dx.doi.org/10.4236/jss.2015.33015

Cebesoy, U. B. (2019). Pre-service teachers' opinions about a two-day climate change education workshop, International Research in Geographical and Environmental Education. 28(3), 211-227. https://doi.org/10.1080/10382046.2019.1579982

Cheng, I. N. Y, \& So, W. W. M. (2015). Teachers' environmental literacy and teaching - stories of three Hong Kong primary school teachers. International Research in Geographical and Environmental Education, 24:1, 58-79.

Davis, J. R., Arend, B. D. (2013). Facilitating seven ways of learning. Stylus, Sterling, VA

Değirmenci, Y., \& Ilter, I. (2017). An investigation into geography teachers' use of current events in geography classes. Universal Journal of Educational Research, 5(10), 1806-1817. https://doi.org/10.13189/ujer.2017.051019

Dike, J. W., \& Amadi, N. G. (2016). Teachers awareness of climate change: Implications for innovative teaching. International Journal of Education and Evaluation, 2(6), 24-31.

Dlamini, M. N. (2016). Understanding and teaching climate change in the secondary education geography curriculum in Swaziland. University of Pretoria, South Africa.

Doyle, T. (2011). Learner-centered teaching: putting the research on learning into practice. Stylus, Sterling, VA

Dube, C. (2014). Environmental concerns in the geography curriculum perceptions of South African high school teachers. Southern African Journal of Environmental Education, 30, 130-146.

Duval, N., \& Kanene, K. M. (2016). Implementation of environmental education (EE) in history in Seychelles: The case of the Beau Vallon Secondary School. International Journal of Scientific Research in Education, 9(2), 105-114.

Ekpoh, U. I., \& Ekpoh, I. J. (2011). Assessing the level of climate change awareness among secondary school teachers in Calabar Municipality, Nigeria: Implication for Management Effectiveness. International Journal of Humanities and Social Science, 1(3), 106-110.

Eze, E. (2020). Sociographic analysis of climate change awareness and pro-environmental behaviour of secondary school teachers and students in Nsukka local government area of Enugu State Nigeria. International Research in Geographical and Environmental Education, 29:1, 89-105, https://doi.org/10.1080/10382046.2019.1657683 
Eze, E. (2021). Why secondary school geography students perform poorly in external examinations. Journal of Geography, 120(2), 51-60. https://doi.org/10.1080/00221341.2020.1860114

Ezeudu, A. S. (2003). Environmental education for sustainable development: A Nigerian perspective. Nigeria: Bel's Books.

Federal Ministry of Education (2017). Nigeria Education Indicators 2016.

Green, M. (2012). Place, sustainability and literacy in environmental education: Frameworks for teaching and learning. Review of International Geographical Education Online, 2, 326-346.

Herman, B. C., Feldman, A., \& Vernaza-Hernandez, V. (2017). Florida and Puerto Rico secondary science teachers' knowledge and teaching of climate change science. International Journal of Science and Mathematics Education, 15(3), 451-471.

Hermans, M. (2016). Geography teachers and climate change: Emotions about consequences, coping strategies, and views on mitigation. International Journal of Environmental \& Science Education, 11(4), 389-408.

Hill, A. (2013). The place of experience and the experience of place: Intersections between sustainability education and outdoor learning. Australian Journal of Environmental Education, 29, $18-32$.

Ho, L., \& Seow, T. (2015). Theory \& research in social education teaching controversial issues in geography: Climate change education in Singaporean schools. Theory \& Research in Social Education, 43, 314-344.

Ikoro, I. S., \& Ezeanyim, U. E. (2016). Assessment of secondary school science teachers' knowledge of climate change in the south east Nigeria, for inclusion in the secondary school curriculum. International Journal of Weather, Climate Change and Conservation Research, 2(3), 9-19.

Jenkins, A., \& Keene, P. (1979). Use posters in your teaching. Journal of Geography in Higher Education, 3(1), 26-26. https://doi.org/10.1080/03098267908708692

Kaiser, H. F. (1974). An index of factorial simplicity. Psychometrika, 39,31-36.

Karpudewan, M., \& Khan, N. S. M. A. (2017). Experiential-based climate change education: Fostering students' knowledge and motivation towards the environment. International Research in Geographical and Environmental Education, 26(3), 207-222.

Kleeman, G. (2006). Not just for fun: Using cartoons to investigate geographical issues. New Zealand Geographer, 62, 144-151.

Kober, N. (2015). Reaching students: What research says about effective instruction in undergraduate science and engineering. The National Academies Press, Washington, DC

Kurtze J., Morais M., Platko, E., \& Thompson, H. (2015). Advancing water management strategies in Morocco. Report to Ribat Al Fath Association for Sustainable Development. Rabat, Morocco.
Loubser, C., \& Simalumba, P. (2016). The implementation of environmental education in geography (grades 8 10) in the Caprivi Region, Namibia. Southern African Journal of Environmental Education, 32, 51-65.

Makrakis, V., Larios, N., \& Kaliantzi, G. (2012). ICTenabled climate change education for sustainable development across the school curriculum. Journal of Teacher Education for Sustainability, 14(2), 54-72.

McPartland, M. (2001). Moral dilemmas, narrative and the teaching of geography. International Research in Geographical and Environmental Education, 10(2), 114-126.

Mochizuki, Y., \& Bryan, A. (2015). Climate change education in the context of education for sustainable development: Rationale and principles. Journal of Education for Sustainable Development, 9(1), 4-26.

Monroe, M. C., Oxarart, A., \& Plate, R. R. (2013). A role for environmental education in climate change for secondary science educators. Applied Environmental Education \& Communication, 12(1), 4-18.

Monroe, M. C., Plate, R. R., Oxarart, A., Bowers, A., \& Willandia, A. C. (2017). Identifying effective climate change education strategies: A systematic review of the research. Environmental Education Research, 23.

Moser, S. C. (2010). Communicating climate change: History, challenges, process and future directions. WIREs Climate Change, 1, 31-53.

Nakpodia, E. D. (2008). The role of educational administration in the promotion of in-service teacher education for primary school teachers in Nigeria. Current issues in educational management in Nigeria. Benin City: Ambik Press.

Ogunbiyi, J. O., \& Ajiboye, J. O. (2009). Pre-service teachers' knowledge of and attitudes to some environmental education concepts using value education strategies. The Anthropologist, 11(4), 293301.

Ogunseemi, O. E., \& Ibimilua, F. O. (2016). Assessment of science teachers' perception of climate change: implication for climate change education in schools in Nigeria. International Journal of Advanced Academic Research. 2 (8), 11-18.

Oluk, S., \& Özalp, I. (2007). The teaching of global environmental problems according to the constructivist approach: As a focal point of the problem and the availability of concept cartoons. Educational Sciences: Theory \& Practice, 7(2), 881-896.

Onuoha, J. C., \& Eze, E. (2013). Analysis of students' attitude towards the study of Geography in Nsukka Local Government Area of Enugu state. African Review of Arts, Social Sciences \& Education, 3(1), 141-157.

Orr, D. (1992). Ecological literacy: Education for a postmodern world. Albany, NY: State University of New York.

Osa, J. O., \& Musser, L. R. (2004). The role of posters in teacher education programs. Education Libraries, 27(1), 16-21. 
Osinem, E. C., \& Nwoji, U. C. (2010). Students industrial work experience in Nigeria: Concepts, principles and practice. Enugu: Cheston Agency Ltd.

Otitoju, M. A., \& Enete, A. A. (2016). Climate change adaptation: Uncovering constraints to the use of adaptation strategies among food crop farmers in South-west, Nigeria using principal component analysis (PCA). Cogent Food \& Agriculture (2016), 2: 1178692

Oversby, J. (2015). Teachers' learning about CCE. Procedia - Social and Behavioral Sciences. 167, 2327.

Ozioko, R. I., Dimelu, M. U., \& Madukwe, M. C. (2013). Capacity for teaching climate change adaptation in the University Faculties of Agriculture in South East Nigeria. Agro-Science Journal of Tropical Agriculture, Food. Environment and Extension, 12(1), 48-58.

Plutzer, E., McCaffrey, M., Hannah, A., Rosenau, J., Berbeco, M., \& Reid, A. (2016). Climate confusion among U.S. teachers. Science, 351(6274), 664-665.

Ronald, M. A., Merab, K. A., \& Byalusaago, M. C. (2017). Impact of secondary school geography content in mitigating climate change In Uganda. IOSR Journal of Environmental Science, Toxicology and Food Technology (IOSR-JESTFT), 11(7), 35-43.

Siegner, A. (2018). Experiential climate change education: Challenges of conducting mixed-methods, interdisciplinary research in San Juan Islands, WA, and Oakland, CA. Energy Research and Social Science, 45, 374-384.

Siegner, A., \& Stapert, N. (2019). Climate change education in the humanities classroom: A case study of the Lowell school curriculum pilot. Environmental Education Research. 26(4), 511-531. https://doi.org/10.1080/13504622.2019.1607258

Toledo, M. A., Rosanelia T. Yangco, \& Espinosa, A. A. (2014). Media cartoons: Effects on 1ssue resolution in environmental education. International Electronic Journal of Environmental Education, 4(1), 19-50. https://doi.org/10.18497/iejee-green. 99250

UNESCO (2017). Education for sustainable development goals: Learning objectives. Paris: UNESCO. https://unesdoc. unesco.org/ark:/48223/pf0000247444

UNFCCC (2001). Report of the Conference of the Parties on its Seventh Session, held at Marrakesh from 29 October to 10 November 2001. FCCC/CP/2001/13/Add.1. 21 January. United Nations Framework Convention on Climate change, Bonn.

Watkins R., Meiers, M. W., \& Visser, Y. L. (2012). A guide to assessing needs. Washington DC: World Bank.

Yamane, T. (1967). Statistics: An introductory analysis, 2nd Edition, New York: Harper and Row. 


\section{APPENDIX 1}

\section{Teachers' Capacity Building Needs on Climate Change Education Strategies (TCBNCCES)}

SECTION A: Personal Information

Gender: Male () Female () Location of service: Rural () Urban ()

Academic Field: Sciences () Social Sciences () Arts ( ) Teaching subject:

Highest Educational Qualification:

SSCE ( ) NCE ( ) B.Sc./B.Ed./B.A. ( ) M.Sc./M.Ed/M.A ( )

Years of Teaching Experience:

1-5 years ( ) 6-10 years ( ) 11-15 years ( ) 16-20 years ( ) >20years ()

Section B: Capacity Building Needs

Circle appropriate responses as follows

Strategies of climate change education instruction delivery

\section{Kindly indicate your level of need for capacity building on each of the following teaching techniques}

Please see the scoring below before responding to the under-listed items

$5=$ Very Highly Needed; $4=$ Highly Needed; $3=$ Moderately Needed;

$2=$ Less Needed; $1=$ Not Needed
Rate your capacity building need on this concept

\begin{tabular}{lllllll}
\hline 1 & 2= Less Needed; 1 = Not Needed & & & & \\
2 & Projects & 1 & 2 & 3 & 4 & 5 \\
3 & Value clarification & 1 & 2 & 3 & 4 & 5 \\
4 & Moral dilemma & 1 & 2 & 3 & 4 & 5 \\
5 & Role playing & 1 & 2 & 3 & 4 & 5 \\
6 & Community-based resources & 1 & 2 & 3 & 4 & 5 \\
7 & Resource persons & 1 & 2 & 3 & 4 & 5 \\
8 & Concept mapping & 1 & 2 & 3 & 4 & 5 \\
9 & Posters & 1 & 2 & 3 & 4 & 5 \\
10 & Cartoons & 1 & 2 & 3 & 4 & 5 \\
11 & Newspaper cuttings & 1 & 2 & 3 & 4 & 5 \\
\end{tabular}

